\title{
オーステナイト系ステンレス鋼の応力腐食割れに およ医す燐および窒素の影響*
}

\author{
小若 正 倫 ${ }^{* *}$ 富士川 尚 男**
}

Masamichi Kowaka and Hisao Fujikawa : Effects of Phosphorus and Nitrogen on Stress Corrosion Cracking of Austenitic Stainless Steels in Boiling $\mathrm{MgCl}_{2}$ Solution. The commercial grades of austenitic stainless steel $(18 \mathrm{Cr}-10 \mathrm{Ni}$ ) may be subjected to stress corrosion cracking when exposed to tensile stress and certain chloride environments. An extensive study was undertaken to develope a steel resistant to stress corrosion cracking. The influence of phosphorus and nitrogen in austenitic stainless steels on stress corrosion cracking has been investigated in boiling $\mathrm{MgCl}_{2}$ at $154^{\circ} \mathrm{C}$ by the U-bend and tensile method. The results of the study showed the detrimental effect of phosphorus and nitrogen and the interaction of these elements on the sensitivity to stress corrosion cracking. A new stainless steel resistant to stress corrosion cracking can be developed by controlling the contents of phosphorus and nitrogen in $18 \mathrm{Cr}-10 \mathrm{Ni}$ stainless steel.

The results were understood by observing the dislocation structures of these steels, by measuring the general corrosion rates and potential-time relations in boiling $\mathrm{MgCl}_{2}$ solution at $154^{\circ} \mathrm{C}$.

(Received July 22, 1970)

\section{I. 緒商}

オーステナイト系ステンレス鋼の沸騰塩化マグネシウム 容液中での応力腐企割れに持よぼす成分元素の影響につい ては，古くより多くの研究が行なわ机ている(1)(2). なた最 近総合的な報告もなされている(3). それらによると応力腐 食割れ感受性を低くする元素はNi 特よびSiであり，感受 性を高める元索は土に $\mathrm{Cr}, \mathrm{Mo}, \mathrm{P}, \mathrm{N}$ などであるといわれ ている.しかしこれらの研究は基合金の主成分 $\mathrm{Cr}$ 叔よび Ni 量が異なっていたり，また添加元素の影響をみるため には通常会恋九ている不純物程度の量からさらに多量に加 えることによってその効果を論じているため, 得られた結 椝の評価が相反するような場合もある。

** 住友金属工業株式会社中央技術研究所 (Central Research Laboratories, Sumitomo Metal Industries, Ltd., Amagasaki)

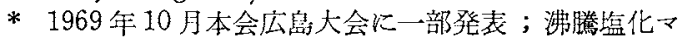
グネシウム浴液中に敊けるオーステナイト系ステン レス鋼の㐫力腐食制肌に関する研究(第 1 報)

(1) Physical Metallurgy of Stress Corrosion Fracture, Interscience Pub. /New York (1959).

(2) H.L.Logan : The Stress Corrosion of Metals, John Wiley and Sons. Inc., New York (1966) .

(3) Fundamental Aspects of Stress Corrosion Cracking, NACE (1967) .
$\mathrm{P}$ の效果については Lang ${ }^{(4)}$ は $18 \mathrm{Cr}-20 \mathrm{Ni}$ 鋼を基本と して0.065 0.35\% 添加してその悪影響をたしかめ, Swann ${ }^{(5)}$ 《 $20 \mathrm{Cr}-20 \mathrm{Ni}$ 鋼を基本として $0.35 \%$ 添加すると 平行転位構造をとることにより割れ感受性を增す元素であ ると報告し, Thomas $5^{(6)}$ は $20 \mathrm{Cr}-20 \mathrm{Ni}$ 鋼に $0.3 \% \mathrm{P}$ を添 加したるのあるいは Staehle ら ${ }^{(7)}$ は $20 \mathrm{Cr}-15 \mathrm{Ni}$ 鋼に0.16 $\% \mathrm{Pを}$ を添加したものを用いて機構の解明を試みようとして いる. Nの効果についてはUhlig らが一連の研究で $\mathrm{N}$ の悪 影響を報告している ${ }^{(8)}{ }^{(9)}$. 密た Rooyen ${ }^{(10)}$ 及び Vaughan (11) らはNは割れ感受性を高めると述べている。また一部では

(4) F.S.Lang : Corrosion, 18 (1962), 378 t.

(5) P.R.Swann : ibid, 19(1963), 102 t.

(6) K.C.Thomas, R.Stickler and R.J.Allio : Corr.Sci., $5(1965), 71$.

(7) T.J.Smith and R.W.Staehle : Corrosion, 23 (1967), 117.

(8) H.H. Uhlig, R.A. White and V.Lincoln Jr. : Acta Met., $5(1957), 473$.

(9) H.H. Uhlig, R. A. White : Trans.ASM, 52 (1960), 830.

(10) D. Van Rooyen : Proceedings of First International Conference on Stress Corrosion Cracking, Butterworths, London, 1961.

(11) D.A.Vaughan, D.I.Phalen, C.L.Peterson and W. K. Boyd : Corrosion, 19 (1963), 315t. 
Nはあまり悪影響はないともいわれている。

上述の上5に応力腐食割れ感受性を低くする元素は $\mathrm{Ni}$ 怙よび $\mathrm{Si}$ であるが，前者を添加することによって応力腐 食割れに対して免疫性を得るのには $45 \%$ 以上が必要であ り，加工性招よび容接性に難を生ずる。著者らは主として
応力腐食割れに悪影響をおよぼす元素を少なくすることに よって，耐応力腐食割れステンレス鋼の開発を試みている

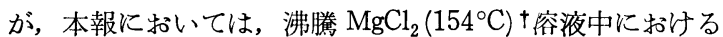
$18 \mathrm{Cr}-10 \mathrm{Ni}$ 鋼を基本成分として $\mathrm{P}$ および $\mathrm{N}$ の影響を明ら かにした。

Table 1 Effect of phosphorus and nitrogen on the susceptibility to stress corrosion cracking of $18 \mathrm{Cr}-10 \mathrm{Ni}$ stainless steels by U-bend method in $\mathrm{MgCl}_{2}$ solution boiling at $154 \mathrm{C}$

\begin{tabular}{|c|c|c|c|c|c|c|c|c|c|c|c|}
\hline \multirow{2}{*}{ No. } & \multicolumn{7}{|c|}{ Chemical composition (wt\%) } & \multirow[b]{2}{*}{$\mathrm{Cr}$} & \multirow[b]{2}{*}{$\mathrm{N}$} & \multirow{2}{*}{\multicolumn{2}{|c|}{$\begin{array}{l}\text { Cracking time } \\
(\mathrm{hr})\end{array}$}} \\
\hline & $\mathrm{C}$ & $\mathrm{Si}$ & $\mathrm{Mn}$ & $\mathrm{P}$ & $\mathrm{S}$ & $\mathrm{Cu}$ & $\mathrm{Ni}$ & & & & \\
\hline $\begin{array}{r}1 \\
2 \\
3 \\
4 \\
5 \\
6 \\
7 \\
8 \\
9 \\
10 \\
11 \\
12 \\
13 \\
14 \\
15 \\
16 \\
17 \\
18 \\
19 \\
20 \\
21\end{array}$ & $\begin{array}{l}0.06 \\
0.07 \\
0.06 \\
0.06 \\
0.07 \\
0.06 \\
0.06 \\
0.07 \\
0.07 \\
0.08 \\
0.07 \\
0.06 \\
0.06 \\
0.06 \\
0.06 \\
0.07 \\
0.07 \\
0.07 \\
0.07 \\
0.07 \\
0.07\end{array}$ & $\begin{array}{l}0.52 \\
0.55 \\
0.65 \\
0.82 \\
0.50 \\
0.50 \\
0.65 \\
0.74 \\
0.48 \\
0.52 \\
0.56 \\
0.55 \\
0.50 \\
0.55 \\
0.46 \\
0.48 \\
0.47 \\
0.48 \\
0.74 \\
0.47 \\
0.42\end{array}$ & $\begin{array}{l}1.51 \\
1.52 \\
1.41 \\
1.44 \\
1.47 \\
1.38 \\
1.43 \\
1.53 \\
1.36 \\
1.42 \\
1.48 \\
1.48 \\
1.46 \\
1.49 \\
1.48 \\
1.35 \\
1.36 \\
3.68 \\
1.18 \\
1.37 \\
1.26\end{array}$ & $\begin{array}{l}0.003 \\
0.004 \\
0.003 \\
0.003 \\
0.004 \\
0.003 \\
0.004 \\
0.003 \\
0.003 \\
0.003 \\
0.003 \\
0.003 \\
0.003 \\
0.003 \\
0.003 \\
0.004 \\
0.004 \\
0.004 \\
0.003 \\
0.004 \\
0.004\end{array}$ & $\begin{array}{l}0.008 \\
0.010 \\
0.010 \\
0.009 \\
0.011 \\
0.010 \\
0.010 \\
0.005 \\
0.009 \\
0.008 \\
0.010 \\
0.011 \\
0.010 \\
0.010 \\
0.010 \\
0.010 \\
0.010 \\
0.010 \\
0.010 \\
0.009 \\
0.011\end{array}$ & $\begin{array}{l}\sum 0.01 \\
\sum 0.01 \\
\sum 0.01 \\
\sum 0.01 \\
\sum 0.01 \\
\sum 0.01 \\
\sum 0.01 \\
\sum 0.01 \\
\sum 0.01 \\
\sum 0.01 \\
\sum 0.01 \\
\sum 0.01 \\
\sum 0.01 \\
\sum 0.01 \\
\sum 0.01 \\
\sum 0.01 \\
\sum 0.01 \\
<0.01 \\
<0.01\end{array}$ & $\begin{array}{r}10.04 \\
9.87 \\
9.55 \\
10.25 \\
9.95 \\
10.50 \\
9.62 \\
9.95 \\
9.78 \\
9.88 \\
10.14 \\
9.66 \\
10.38 \\
9.81 \\
10.14 \\
10.44 \\
10.44 \\
9.92 \\
10.17 \\
10.18 \\
10.47\end{array}$ & $\begin{array}{l}17.87 \\
18.24 \\
18.11 \\
17.90 \\
18.32 \\
18.57 \\
17.88 \\
17.84 \\
18.00 \\
18.46 \\
18.22 \\
18.27 \\
17.56 \\
18.32 \\
17.90 \\
18.36 \\
18.15 \\
18.06 \\
17.90 \\
18.19 \\
18.01\end{array}$ & $\begin{array}{l}0.007 \\
0.009 \\
0.010 \\
0.015 \\
0.018 \\
0.020 \\
0.021 \\
0.023 \\
0.026 \\
0.031 \\
0.033 \\
0.042 \\
0.051 \\
0.063 \\
0.077 \\
0.078 \\
0.092 \\
0.101 \\
0.149 \\
0.176 \\
0.342\end{array}$ & 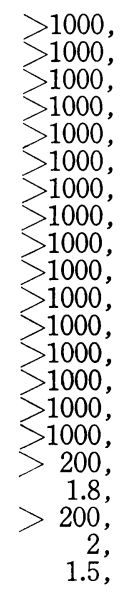 & $\begin{array}{r}>1000 \\
>1000 \\
>1000 \\
>1000 \\
>1000 \\
>1000 \\
>1000 \\
>1000 \\
>1000 \\
>1000 \\
>1000 \\
>1000 \\
>1000 \\
89 \\
5 \\
2.2 \\
>200 \\
2 \\
2\end{array}$ \\
\hline $\begin{array}{l}22 \\
23 \\
24 \\
25 \\
26 \\
27 \\
28 \\
29 \\
30 \\
31 \\
32 \\
33 \\
34\end{array}$ & $\begin{array}{l}0.08 \\
0.07 \\
0.05 \\
0.07 \\
0.07 \\
0.07 \\
0.08 \\
0.06 \\
0.06 \\
0.06 \\
0.08 \\
0.06 \\
0.07\end{array}$ & $\begin{array}{l}0.59 \\
0.52 \\
0.46 \\
0.41 \\
0.52 \\
0.40 \\
0.87 \\
0.73 \\
0.50 \\
1.10 \\
0.34 \\
0.49 \\
0.40\end{array}$ & $\begin{array}{l}1.51 \\
1.52 \\
1.48 \\
1.46 \\
1.54 \\
1.53 \\
1.35 \\
1.52 \\
1.50 \\
1.47 \\
1.24 \\
1.22 \\
1.27\end{array}$ & $\begin{array}{l}0.009 \\
0.006 \\
0.006 \\
0.007 \\
0.007 \\
0.006 \\
0.008 \\
0.009 \\
0.006 \\
0.008 \\
0.005 \\
0.006 \\
0.005\end{array}$ & $\begin{array}{l}0.008 \\
0.011 \\
0.015 \\
0.015 \\
0.010 \\
0.010 \\
0.018 \\
0.005 \\
0.010 \\
0.004 \\
0.012 \\
0.010 \\
0.010\end{array}$ & $\begin{array}{l}<0.01 \\
\sum 0.01 \\
\sum 0.01 \\
<0.01 \\
<0.01 \\
0.01 \\
<0.01 \\
<0.01 \\
0.17 \\
<0.01 \\
\sum 0.01 \\
<0.01\end{array}$ & $\begin{array}{r}10.61 \\
10.00 \\
10.20 \\
10.20 \\
10.04 \\
9.50 \\
10.17 \\
9.83 \\
9.94 \\
9.49 \\
9.18 \\
10.23 \\
10.30\end{array}$ & $\begin{array}{l}16.95 \\
1824 \\
17.97 \\
17.91 \\
17.82 \\
18.38 \\
18.60 \\
17.75 \\
17.71 \\
18.32 \\
17.60 \\
18.42 \\
17.84\end{array}$ & $\begin{array}{l}0.007 \\
0.014 \\
0.015 \\
0.014 \\
0.028 \\
0.031 \\
0.031 \\
0.037 \\
0.042 \\
0.046 \\
0.047 \\
0.158 \\
0299\end{array}$ & $\begin{array}{r}>1000 \\
>1000 \\
26, \\
21 \\
>1000 \\
102, \\
3.5, \\
>1000 \\
>1000 \\
2.7 \\
3, \\
3, \\
1,\end{array}$ & $\begin{array}{r}>1000 \\
>1000 \\
6 \\
8 \\
69 \\
45 \\
6.5 \\
410 \\
20 \\
4.4 \\
21 \\
1.5 \\
2\end{array}$ \\
\hline $\begin{array}{l}35 \\
36 \\
37 \\
38 \\
39 \\
40 \\
41 \\
42 \\
43 \\
44\end{array}$ & $\begin{array}{l}0.07 \\
0.07 \\
0.08 \\
0.06 \\
0.06 \\
0.08 \\
0.07 \\
0.07 \\
0.08 \\
0.08\end{array}$ & $\begin{array}{l}0.57 \\
0.47 \\
066 \\
0.47 \\
0.39 \\
0.62 \\
0.46 \\
0.52 \\
0.75 \\
0.79\end{array}$ & $\begin{array}{l}1.58 \\
1.48 \\
1.39 \\
1.41 \\
1.47 \\
1.42 \\
1.42 \\
1.36 \\
1.32 \\
1.35\end{array}$ & $\begin{array}{l}0.010 \\
0.012 \\
0.012 \\
0.011 \\
0.014 \\
0.010 \\
0.011 \\
0.010 \\
0.014 \\
0.017\end{array}$ & $\begin{array}{l}0.014 \\
0.013 \\
0.010 \\
0.010 \\
0.013 \\
0.008 \\
0.013 \\
0.012 \\
0.011 \\
0.010\end{array}$ & $\begin{array}{l}<0.01 \\
0.02 \\
<0.01 \\
<0.01 \\
<0.01 \\
0.02 \\
<0.01 \\
<0.01 \\
<0.01 \\
<0.01\end{array}$ & $\begin{array}{r}10.08 \\
10.25 \\
9.77 \\
10.45 \\
10.25 \\
9.21 \\
9.61 \\
9.73 \\
9.58 \\
9.38\end{array}$ & $\begin{array}{l}17.71 \\
18.10 \\
18.06 \\
17.71 \\
17.83 \\
18.13 \\
18.10 \\
18.13 \\
18.47 \\
18.38\end{array}$ & $\begin{array}{l}0.018 \\
0.015 \\
0.021 \\
0.021 \\
0.014 \\
0.029 \\
0.029 \\
0.058 \\
0.069 \\
0.159\end{array}$ & $\begin{array}{r}>1000 \\
45 \\
>1000 \\
7 \\
45 \\
5 \\
7 \\
5 \\
21 \\
45\end{array}$ & $\begin{array}{r}>1000 \\
6 \\
21 \\
42 \\
6 \\
7 \\
14 \\
5 \\
8 \\
45\end{array}$ \\
\hline $\begin{array}{l}45 \\
46 \\
47 \\
48 \\
49 \\
50 \\
51 \\
52 \\
53\end{array}$ & $\begin{array}{l}0.07 \\
0.07 \\
0.06 \\
0.08 \\
0.08 \\
0.07 \\
0.06 \\
0.08 \\
0.08\end{array}$ & $\begin{array}{l}0.68 \\
0.61 \\
0.67 \\
0.60 \\
0.72 \\
0.79 \\
1.02 \\
0.79 \\
0.78\end{array}$ & $\begin{array}{l}1.57 \\
1.55 \\
1.43 \\
1.53 \\
1.11 \\
1.57 \\
1.43 \\
1.34 \\
1.30\end{array}$ & $\begin{array}{l}0.017 \\
0.025 \\
0.027 \\
0.026 \\
0.024 \\
0.031 \\
0.021 \\
0.034 \\
0.030\end{array}$ & $\begin{array}{l}0.013 \\
0012 \\
0.010 \\
0.013 \\
0.010 \\
0.005 \\
0.014 \\
0.011 \\
0.017\end{array}$ & $\begin{array}{l}<0.01 \\
\sum 0.01 \\
<0.01 \\
<0.01 \\
<0.01 \\
<0.01 \\
0.17 \\
<0.01 \\
<0.01\end{array}$ & $\begin{array}{r}10.61 \\
10.31 \\
9.55 \\
8.76 \\
9.99 \\
9.93 \\
9.54 \\
9.52 \\
9.45\end{array}$ & $\begin{array}{l}18.82 \\
18.28 \\
17.80 \\
18.16 \\
18.27 \\
177.77 \\
18.19 \\
18.57 \\
18.56\end{array}$ & $\begin{array}{l}0.007 \\
0.007 \\
0.007 \\
0.028 \\
0.030 \\
0.034 \\
0.044 \\
0.067 \\
0.067\end{array}$ & $\begin{array}{l}1.5 \\
3.5 \\
70 \\
3, \\
3.4, \\
3, \\
2.7 \\
2.7 \\
2.7 \\
\text {, }\end{array}$ & $\begin{array}{r}1.5 \\
3.5 \\
164 \\
4 \\
4 \\
3 \\
2.7 \\
2.7 \\
2.7\end{array}$ \\
\hline $\begin{array}{l}54 \\
55 \\
56\end{array}$ & $\begin{array}{l}0.07 \\
0.07 \\
0.07\end{array}$ & $\begin{array}{l}0.49 \\
0.49 \\
0.52\end{array}$ & $\begin{array}{l}1.46 \\
1.42 \\
1.46\end{array}$ & $\begin{array}{l}0.071 \\
0.130 \\
0.205\end{array}$ & $\begin{array}{l}0.013 \\
0.013 \\
0.012\end{array}$ & $\begin{array}{l}<0.01 \\
<0.01 \\
<0.01\end{array}$ & $\begin{array}{l}10.18 \\
10.04 \\
10.27\end{array}$ & $\begin{array}{l}18.20 \\
18.12 \\
17.90\end{array}$ & $\begin{array}{l}0.014 \\
0.014 \\
0.017\end{array}$ & $\begin{array}{l}3, \\
3, \\
3,\end{array}$ & $\begin{array}{l}3 \\
3 \\
3\end{array}$ \\
\hline 57 & 0.06 & 0.53 & 1.51 & 0.027 & 0.007 & 0.10 & 9.85 & 18.15 & 0.032 & 1, & 1 \\
\hline
\end{tabular}




\section{II. 供試材および実験方法}

\section{1. 供 試 材}

$18 \mathrm{Cr}-10 \mathrm{Ni}$ 鋼, $18 \mathrm{Cr}-13.5 \mathrm{Ni}$ 鋼および $18 \mathrm{Cr}-15 \mathrm{Ni}$ 鋼 を基本としてP执よびN含有量を種々変えたものを高周波 炉により $20 〜 30 \mathrm{~kg}$ 鋼塊を溶製した。試験片は厚さ $7 \mathrm{~mm}$ の板㧊よび $13 \mathrm{~mm} \phi$ の丸棒に鍛伸熱延し,さらに板は 4.9 $\mathrm{mm}$ の厚さまで泠延した後いずれも $1100^{\circ} \mathrm{C} \times 30 \mathrm{~min} \mathrm{W.Q.}$ の溶体化処理を行ない， $10 \times 75 \times 2 \mathrm{~mm}$ の短冊型および平 行部 $3 \phi \times 20 \mathrm{~mm}$ の引張型の試験片に加工した.な格腐 量測定に用いた試験片は 10 × 35 × $2 \mathrm{~mm}$ の短冊型のものを 主として用いた。供試材の化学組成は Table 1 に記す。

\section{2. 応力腐食割れ試験}

上記の短冊型の試験片をエメリー紙＃０にて研摩し, 機 械加工の影響を除くために真空中で $1050^{\circ} \mathrm{C} \times 5$ min A.C. により応力除去焼鈍を行ない，さらに表面の酸化皮膜を除 去するために軽くエメリー紙＃０にて研摩した。これをU 字型 (5R)に曲げてステンスレス製のボルト执よびナット で拘束し, 脱脂洗條後沸騰 $\mathrm{MgCl}_{2}\left(154^{\circ} \mathrm{C}\right)$ 溶液中に浸漬し, 所定の時間毎に割れの発生を調べた。

引張型の試験片は電解研摩を行ない, 脱脂洗滌後所定の 応力を付加して試験した。

\section{3. 薄膜の直接観察}

試験片を $1050^{\circ} \mathrm{C} \times 5 \mathrm{~min}$ A.C.の真空焼鈍した後に引張 加工により $0 \sim 5 \%$ 歪を与兄, $\mathrm{HCl}-\mathrm{HF}-\mathrm{H}_{2} \mathrm{O}_{2}$ 溶液で化学研 摩後 $\mathrm{H}_{3} \mathrm{PO}_{4}-\mathrm{CrO}_{3}$ 溶液中で電解研摩により薄膜とした。 こ の薄膜を脱脂洗滌後, 電子顕微鏡 (加速電圧 $200 \mathrm{kV}$ ) にて 観察した.

\section{4. 腐食試験}

U-bend 法による応力腐食割れ試験片と同様の処理をし た $10 \times 35 \times 2 \mathrm{~mm}$ の短冊型の試験片について, 沸騰 $\mathrm{MgCl}_{2}$ $\left(154^{\circ} \mathrm{C}\right)$ 溶液中で応 力を付加せず所定の時間毎に腐食量を 測定した.

\section{5. 電 位 測 定}

定荷重を与えた試験片の電位の経時変化を求めた。試験 方法は Fig.1 に示す.

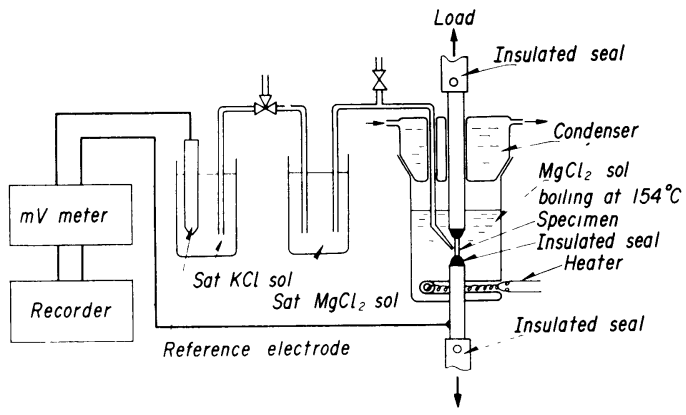

Fig.1 Apparatus for measuring potential
III. 実 験 結 果

\section{1. 応力腐食割れ試験}

\section{(1) $18 \mathrm{Cr}-10 \mathrm{Ni}$ 鋼の場合}

$18 \mathrm{Cr}-10 \mathrm{Ni}$ 鋼を基本として $\mathrm{P}$ および $\mathrm{N}$ 含有量を種々変 えた材料について, 沸騰 $\mathrm{MgCl}_{2}\left(154^{\circ} \mathrm{C}\right)$ 溶液中で U-bend 法による応力腐食割れ試験を行なった結果を供試材の化学 組成とともに Table 1 に示す。な特この試験で 1000 時間 以上浸漬しても割れを発生しないものと割れを発生したも のについて，PとNとの関係を Fig.2 に示す. この結果, $\mathrm{P}$ およびNのいずれか一方の量がきわめて少ない場合は, 応力腐食割れ感受性が著しく小さいことがわかるすなお ち $\mathrm{P}$ 含有量が $0.003 \mathrm{wt} \%$ 以下の場合， N含有量が約 0.08 $\mathrm{wt} \%$ 程度まで $\mathrm{N}$ 量に無関係に応力腐食割れを生じない.し かし $\mathrm{P}$ 含有量が $0.003 \mathrm{wt} \%$ 以上になると著しく $\mathrm{N}$ 量の影 響をうけるようになる.たとえばP含有量が 0.005 wt\%に なると $\mathrm{N}$ 含有量を約 $0.016 \mathrm{wt} \%$ 程度を境としてこれより 少ない $\mathrm{N}$ 量の場合には, 割れ感受性は著しく小さく 1000 時間経ても割れを生じないが， $\mathrm{N}$ 含有量がこれより少しで も増すと応力腐食割れ感受性が著しく大きくなり，数時間 で割れを発生する.Photo.1 に主な顕微鏡観察の結果を示 す.割れたものは $\mathrm{MgCl}_{2}$ 溶液中での典型的な粒内割れで ある.

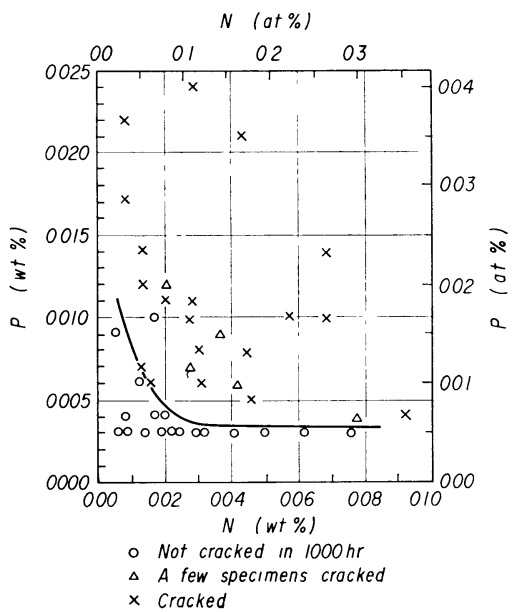

Fig.2 Effect of phosphorus and nitrogen on stress corrosion cracking of $18 \mathrm{Cr}-10 \mathrm{Ni}$ stainless steels in $\mathrm{MgCl}_{2}$ solution boiling at $154^{\circ} \mathrm{C}$ (U-bend method)

つぎに定荷重型の応力腐食割れ試験によりこれら供試材 のらちの主なものについて $30 \mathrm{~kg} / \mathrm{mm}^{2}$ 引張応力を付加し た場合の破断時間を Table 2 に示す. U-bend 法で 1000 時 間以上割れを発生しなかった鋼種は 6000 分以上割れない が，U-bend 法で割れたもののほとんどが短時間に破断に 至っているのが認められる.

(2) $18 \mathrm{Cr}-13.5 \mathrm{Ni}$ 鋼の場合

$\mathrm{Ni}$ が応力腐食割れ感受性に有効であることは周知の事 


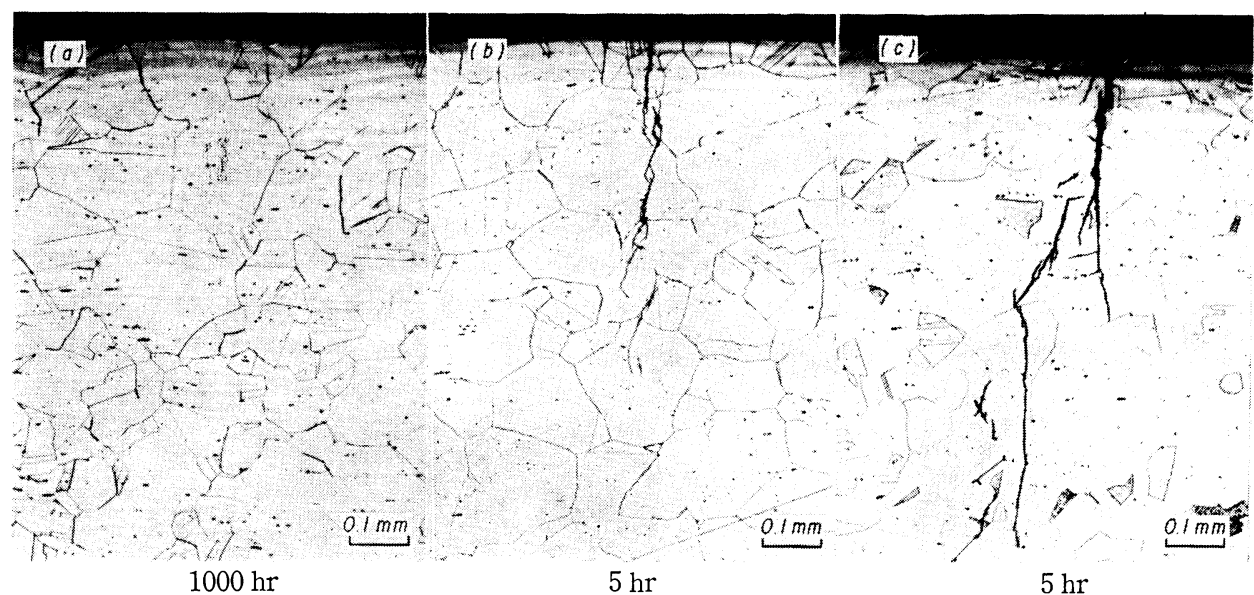

No. $4(0.003 \% \mathrm{P}, 0.015 \% \mathrm{~N}) \quad$ No. $54(0.071 \% \mathrm{P}, 0.014 \% \mathrm{~N}) \quad$ No. $20(0.004 \% \mathrm{P}, 0.176 \% \mathrm{~N})$

Photo. 1 Cross section of specimens No.4, 20 and 54 after stress corrosion test by $\mathrm{U}$-bend method in $\mathrm{MgCl}_{2}$ solution boiling at $154^{\circ} \mathrm{C}$

Table 2 Effect of phosphorus and nitrogen on the fracture time of $18 \mathrm{Cr}-10 \mathrm{Ni}$ stainless steels applied stress of $30 \mathrm{~kg} / \mathrm{mm}^{2}$ by the constant load method in $\mathrm{MgCl}_{2}$ solution boiling at $154^{\circ} \mathrm{C}$

\begin{tabular}{r|c|c|c}
\hline No. & $\mathrm{P}$ & $\mathrm{N}$ & $\begin{array}{c}\text { Fracture time } \\
\text { (min) }\end{array}$ \\
\hline 1 & 0.003 & 0.007 & $>6000$ \\
4 & 0.003 & 0.015 & $>6000$ \\
5 & 0.004 & 0.018 & $>6000$ \\
6 & 0.003 & 0.020 & $>6000$ \\
9 & 0.003 & 0.026 & $>6000$ \\
12 & 0.003 & 0.042 & $>6000$ \\
13 & 0.003 & 0.051 & $>6000$ \\
14 & 0.003 & 0.063 & $>6000$ \\
15 & 0.003 & 0.077 & $>6000$ \\
16 & 0.004 & 0.078 & $>6000$ \\
17 & 0.004 & 0.092 & 91 \\
18 & 0.004 & 0.101 & $>6000$ \\
23 & 0.006 & 0.014 & $>6000$ \\
26 & 0.007 & 0.028 & $>6000$ \\
27 & 0.006 & 0.031 & $>6000$ \\
30 & 0.006 & 0.042 & 139 \\
33 & 0.006 & 0.158 & 217 \\
34 & 0.005 & 0.299 & 1075 \\
38 & 0.011 & 0.021 & 124 \\
41 & 0.011 & 0.029 & \\
\hline
\end{tabular}

実であるが, $\mathrm{Ni}$ 量を $13.5 \%$ と増加した場合にP拈よびNの 関係がどのように変わるかを検討した。供試材の化学組成 および U-bend 法による応力腐食割れの試験結果を Table 3 特よび Fig.3 に示す. $\mathrm{Ni}$ 量が 3.5\% 増加したことによ り $\mathrm{P}$ 执よびNの悪影響, 特にNの悪影響が弱められるのが 垫められる.すなわちP含有量が $0.006 \mathrm{wt} \%$ 以下の場合 には約 $0.1 \mathrm{wt} \% \mathrm{~N}$ 含有量では割れを 1000 時間以上発生し なくなっている.

\section{(3) $18 \mathrm{Cr}-15 \mathrm{Ni}$ 鋼の場合}

$18 \mathrm{Cr}-13.5 \mathrm{Ni}$ 鋼を基本とした場合，特にNの悪影響が 弱まったが, さらに Ni 量を増加させて $18 \mathrm{Cr}-15 \mathrm{Ni}$ 鋼を 基本とした場合の P と $\mathrm{N}$ の関係を求めた. 供試材の化学 組成执よび U-bend 法による応力腐食割れの試験結果を Table 4 および Fig.4 に示す. $18 \mathrm{Cr}-13.5 \mathrm{Ni}$ 鋼を基本と した場合よりもさらに著しく $\mathrm{N}$ 悪影響が弱まり, P含有 量が約 $0.01 \sim 0.012 \mathrm{wt} \%$ 以下の場合には, Nの含有量に かかわらず 1000 時間以上割れを発生しなくなっている. しかし $\mathrm{N}$ 量をいかに少なくしても P 含有量が $0.015 \mathrm{wt} \%$

Table 3 Effect of phosphorus and nitrogen on the susceptibility to stress corrosion cracking of $18 \mathrm{Cr}-13.5 \mathrm{Ni}$ stainless steels by the U-bend method in $\mathrm{MgCl}_{2}$ solution boiling at $154^{\circ} \mathrm{C}$

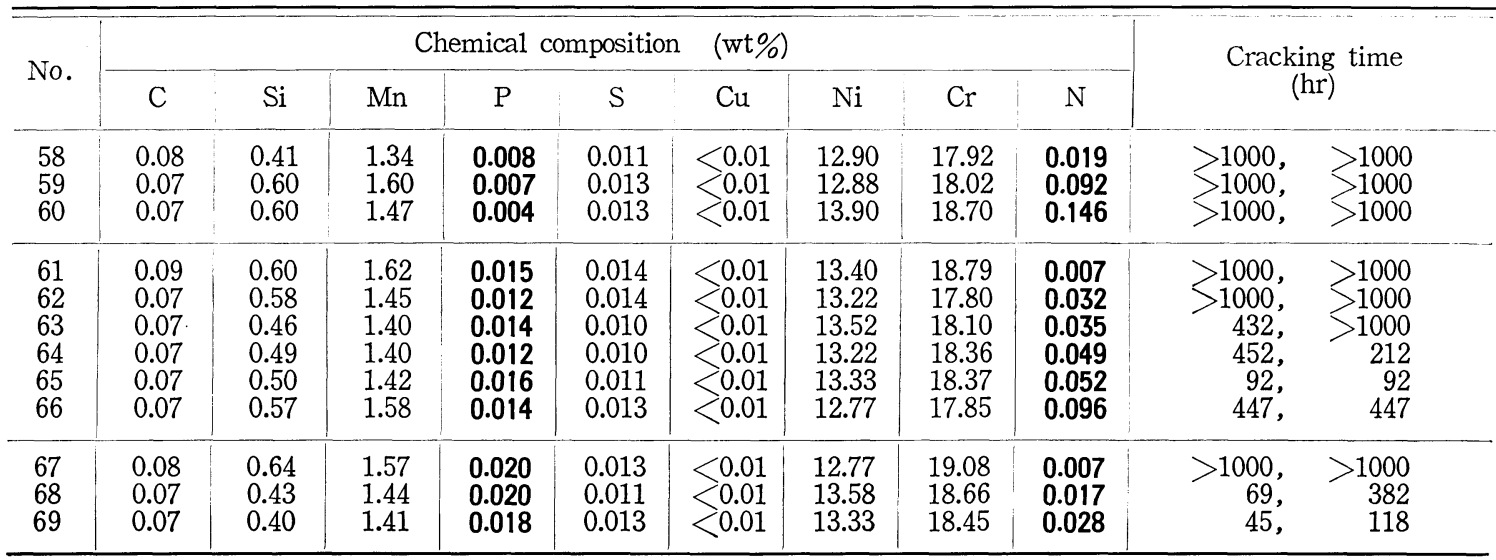




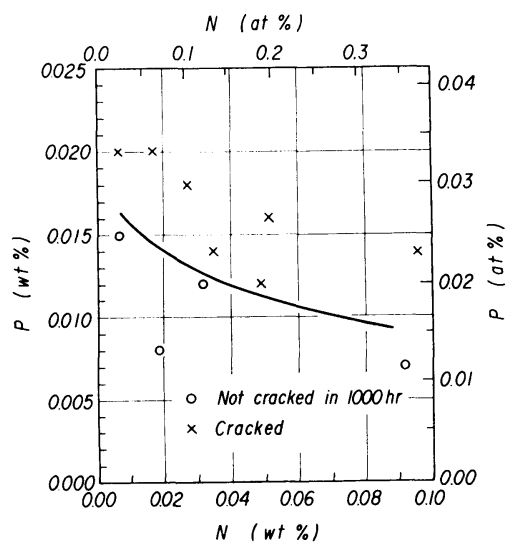

Fig.3 Effect of phosphorus and nitrogen on stress corrosion cracking of $18 \mathrm{Cr}-13.5$ $\mathrm{Ni}$ stainlesss steels in $\mathrm{MgCl}_{2}$ solution boiling at $154^{\circ} \mathrm{C}$ ( $\mathrm{U}$ bend method)

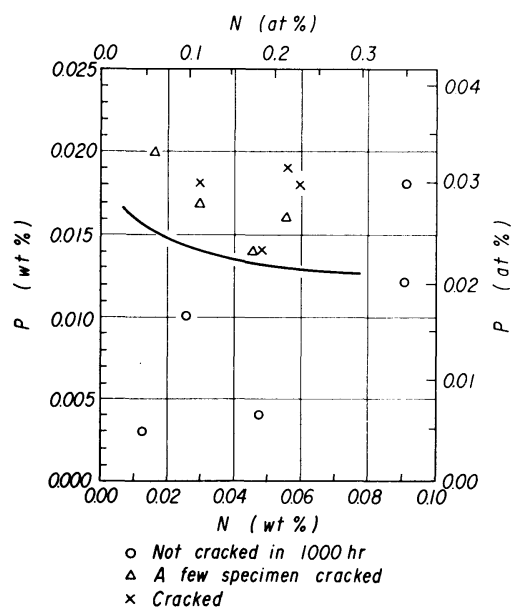

Fig.4 Effect of phosphorus and nitrogen on stress corrosion cracking of $18 \mathrm{Cr}-15$ $\mathrm{Ni}$ stainless steels in $\mathrm{MgCl}_{2}$ solution boiling at $154^{\circ} \mathrm{C}$ (U-bend method)

Table 4 Effect of phosphorus and nitrogen on the susceptibility to stress corrosion cracking of $18 \mathrm{Cr}-15 \mathrm{Ni}$ stainless steels by the U-bend method in $\mathrm{MgCl}_{2}$ solution boiling at $154^{\circ} \mathrm{C}$

\begin{tabular}{|c|c|c|c|c|c|c|c|c|c|c|c|}
\hline \multirow{3}{*}{$\begin{array}{c}\text { No. } \\
\\
70 \\
71 \\
72\end{array}$} & \multicolumn{9}{|c|}{ Chemical composition (wt \%) } & \multirow{2}{*}{\multicolumn{2}{|c|}{$\underset{(\mathrm{hr})}{\text { Cracking time }}$}} \\
\hline & $\mathrm{C}$ & $\mathrm{Si}$ & $\mathrm{Mn}$ & $P$ & $\mathrm{~S}$ & $\mathrm{Cu}$ & $\mathrm{Ni}$ & $\mathrm{Cr}$ & $\mathrm{N}$ & & \\
\hline & $\begin{array}{l}0.07 \\
0.07 \\
0.08\end{array}$ & $\begin{array}{l}0.54 \\
0.53 \\
0.55\end{array}$ & $\begin{array}{l}1.44 \\
1.34 \\
1.39\end{array}$ & $\begin{array}{l}0.003 \\
0.004 \\
0.004\end{array}$ & $\begin{array}{l}0.012 \\
0.014 \\
0.010\end{array}$ & $\begin{array}{l}<0.01 \\
<0.01 \\
<0.01\end{array}$ & $\begin{array}{l}14.95 \\
15.14 \\
15.59\end{array}$ & $\begin{array}{l}17.89 \\
17.75 \\
18.24\end{array}$ & $\begin{array}{l}0.013 \\
0.048 \\
0.177\end{array}$ & $\begin{array}{l}1000, \\
>1000 \\
>1000\end{array}$ & $\begin{array}{l}>1000 \\
>1000 \\
>1000\end{array}$ \\
\hline $\begin{array}{l}73 \\
74 \\
75 \\
76\end{array}$ & $\begin{array}{l}0.10 \\
0.07 \\
0.07 \\
0.08\end{array}$ & $\begin{array}{l}0.72 \\
0.68 \\
0.69 \\
0.55\end{array}$ & $\begin{array}{l}1.55 \\
1.47 \\
1.50 \\
1.53\end{array}$ & $\begin{array}{l}0.010 \\
0.012 \\
0.007 \\
0.009\end{array}$ & $\begin{array}{l}0.013 \\
0.013 \\
0.013 \\
0.013\end{array}$ & $\begin{array}{l}<0.01 \\
<0.01 \\
<0.01 \\
0.01\end{array}$ & $\begin{array}{l}14.70 \\
15.23 \\
15.14 \\
15.48\end{array}$ & $\begin{array}{l}18.98 \\
18.63 \\
18.27 \\
18.13\end{array}$ & $\begin{array}{l}0.026 \\
0.091 \\
0.113 \\
0.118\end{array}$ & $\begin{array}{l}>1000 \\
31000 \\
>1000 \\
>1000\end{array}$ & $\begin{array}{l}>1000 \\
>1000 \\
>1000 \\
>1000\end{array}$ \\
\hline $\begin{array}{l}77 \\
78 \\
79 \\
80 \\
81 \\
82 \\
83 \\
84 \\
85\end{array}$ & $\begin{array}{l}0.08 \\
0.07 \\
0.08 \\
0.08 \\
0.07 \\
0.08 \\
0.07 \\
0.08 \\
0.07\end{array}$ & $\begin{array}{l}0.49 \\
0.46 \\
0.42 \\
0.53 \\
0.55 \\
0.55 \\
0.52 \\
0.60 \\
0.66\end{array}$ & $\begin{array}{l}1.40 \\
1.41 \\
1.45 \\
1.46 \\
1.47 \\
1.45 \\
1.44 \\
1.57 \\
1.48\end{array}$ & $\begin{array}{l}0.020 \\
0.017 \\
0.018 \\
0.014 \\
0.014 \\
0.016 \\
0.019 \\
0.018 \\
0.018\end{array}$ & $\begin{array}{l}0.010 \\
0.011 \\
0.010 \\
0.013 \\
0.014 \\
0.010 \\
0.011 \\
0.013 \\
0.013\end{array}$ & $\begin{array}{l}<0.01 \\
\sum 0.01 \\
\sum 0.01 \\
\sum 0.01 \\
<0.01 \\
<0.01 \\
\sum 0.01 \\
<0.01\end{array}$ & $\begin{array}{l}15.49 \\
16.20 \\
15.83 \\
15.59 \\
15.37 \\
15.20 \\
15.56 \\
15.71 \\
15.23\end{array}$ & $\begin{array}{l}17.40 \\
18.20 \\
18.67 \\
17.89 \\
18.30 \\
18.43 \\
18.68 \\
17.80 \\
18.77\end{array}$ & $\begin{array}{l}0.016 \\
0.030 \\
0.030 \\
0.046 \\
0.048 \\
0.056 \\
0.056 \\
0.060 \\
0.092\end{array}$ & $\begin{array}{r}692 \\
>1000 \\
480 \\
408, \\
480 \\
>1000 \\
92, \\
144, \\
>1000\end{array}$ & $\begin{array}{r}>1000 \\
480 \\
576 \\
>1000 \\
408 \\
576 \\
380 \\
150 \\
>1000\end{array}$ \\
\hline $\begin{array}{l}86 \\
87\end{array}$ & $\begin{array}{l}0.08 \\
0.10\end{array}$ & $\begin{array}{l}0.68 \\
0.65\end{array}$ & $\begin{array}{l}1.45 \\
1.45\end{array}$ & $\begin{array}{l}0.026 \\
0.029\end{array}$ & $\begin{array}{l}0.014 \\
0.012\end{array}$ & $<0.01$ & $\begin{array}{l}15.21 \\
14.70\end{array}$ & $\begin{array}{l}17.89 \\
18.98\end{array}$ & $\begin{array}{l}0.007 \\
0.026\end{array}$ & $\begin{array}{r}>1000 \\
14.8,\end{array}$ & $\begin{array}{r}>1000 \\
118\end{array}$ \\
\hline
\end{tabular}

以上では割れ感受性が高く，この程度の $\mathrm{Ni}$ 量の增加によ ってはPの悪影響を弱めることは不可能である.

したがって Fig.2, 3 打よび 4 で割れを起こさぬ領域の $\mathrm{P}$ と $\mathrm{N}$ 成分にすることによって, 耐応力腐食割れ感受性 の小さいオーステナイト系ステンレス鋼を製造することが できる(12).

\section{2. 転位構造の直接観察}

$\mathrm{P}$ およびNの成分を Fig.2, 3 抢よび 4 の応力腐食割れを 起こさ奴領域にすることによって, 耐応力腐食割れ感受性 のすぐれたステンレ、鋼が得られることから，この領域に

（12）小若，冨士川：別報.
属する No.4 鋼 (0.003 wt\% P, $0.014 \mathrm{wt} \% \mathrm{~N}) ， \mathrm{P}$ を 0.071 $\mathrm{wt} \%$ 含有した No. 54 鋼およびNを $0.176 \mathrm{wt} \%$ 含有した No. 20 鋼を 0 5\% 引張加工した場合の転位構造が, ぞ のように変わるかを観察した結果をPhoto.2 括よび 3 に 示す. Photo. 2 飞示す No. 鋼は焼鈍まま技よび $3 \%$ 引張 加工では一般的な組織であるが，5\%引張加工した場合， 転位は若干 tangle してくる傾向が認められる。しかるに Photo.3 (a) の P 含有量の高い No.54 鋼は $5 \%$ 引張加工で 引張方向に伸びた転位が多数認められる．また $\mathrm{N}$ 含有量が 高い No. 20 鋼は Photo.3 (b) の如く典型的な planar 転位配 列を示している．この成分範囲で $\mathrm{P}$ およびNの含有量の高 い場合，20 Cr-20 Ni 鋼を基本として Swann が観察した転 


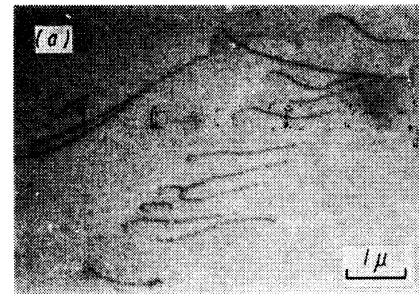

annealed

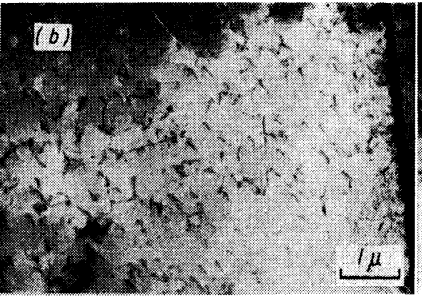

$3 \%$ elongated

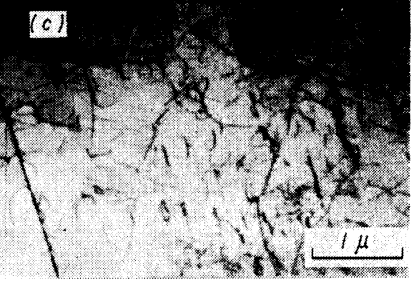

$5 \%$ elongated

Photo. 2 Dislocation structure of annealed, $3 \%$ and $5 \%$ elongated specimens, No. $4(0.003 \%$ P, $0.015 \% \mathrm{~N})$ steel

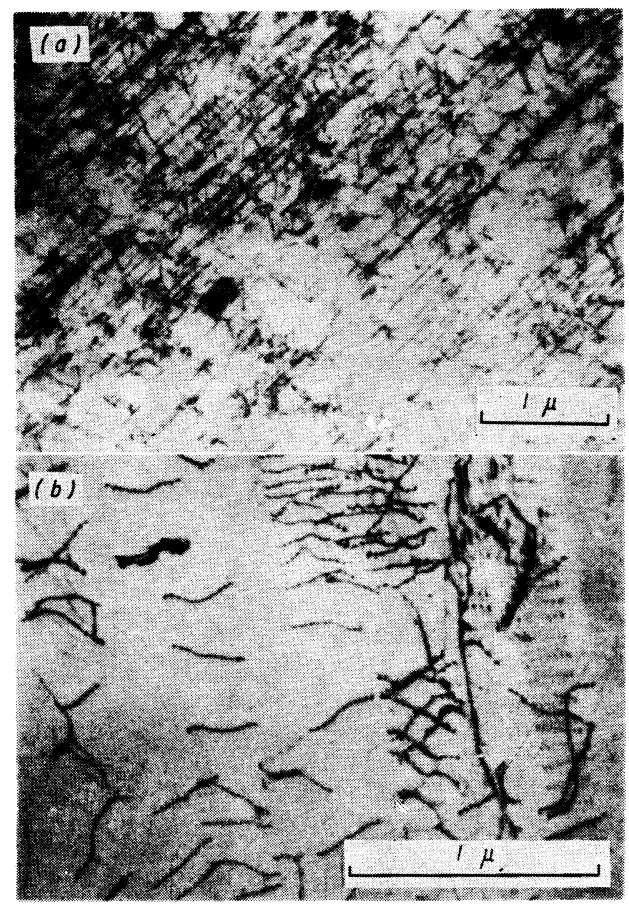

Photo. 3 Dislocation structure of $5 \%$ elongated specimens, No. 54 and 20 steels

(a) No. $54(0.071 \% \mathrm{P}, 0.014 \% \mathrm{~N})$

(b) $\mathrm{No.} 20(0.004 \% \mathrm{P}, 0.176 \% \mathrm{~N})$

位構造とさわめて類似している. しかしこのような転位配 列の相異だけから割れ感受性の相異を説明するには今日で は不十分とされている。したがって著者らは沸騰 $\mathrm{MgCl}_{2}$ $\left(154^{\circ} \mathrm{C}\right)$ 溶液中での腐食性におよぼす成分元素の影響につ いて定量的な報告がないことから，腐食に执よぼす Pおよ びNの挙動を検討した。

\section{3. 腐食試験}

耐応力腐食割れ性のすぐれた No.4 鋼， $0.071 \mathrm{wt} \% \mathrm{P}$ 含 有した No. 54 鋼, 0.078 wt \% N 含有した No.16 鋼执よび $\mathrm{P}$ と $\mathrm{N}$ とに若干高く含有した No. 52 鋼 $(0.034 \mathrm{wt} \% \mathrm{P}$, $0.067 \mathrm{wt} \% \mathrm{~N})$ について，沸騰 $\mathrm{MgCl}_{2}\left(154^{\circ} \mathrm{C}\right)$ 溶液中で腐食 量の測定を行なった. この結果を Fig.5 に示す. No.4 鋼 は他の鋼種に比較して腐食量が若干多いが，P含有量の高 いNo.54 鋼は, もっとも腐食量が少ない. N含有量の高い No.16 鋼は No.4 鋼と顕著な相異は認められない. また $\mathrm{P}$

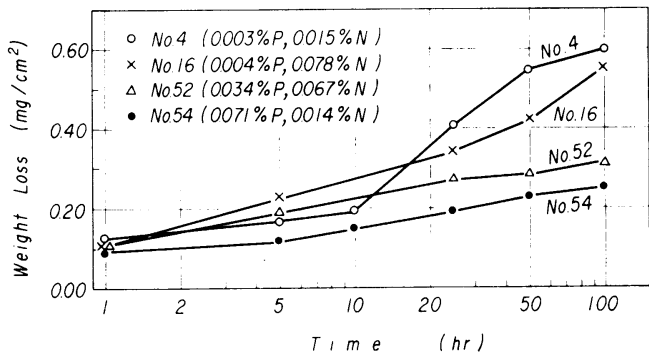

Fig.5 Relationship between weight loss and exposed time in $\mathrm{MgCl}_{2}$ solution boiling at $154^{\circ} \mathrm{C}$

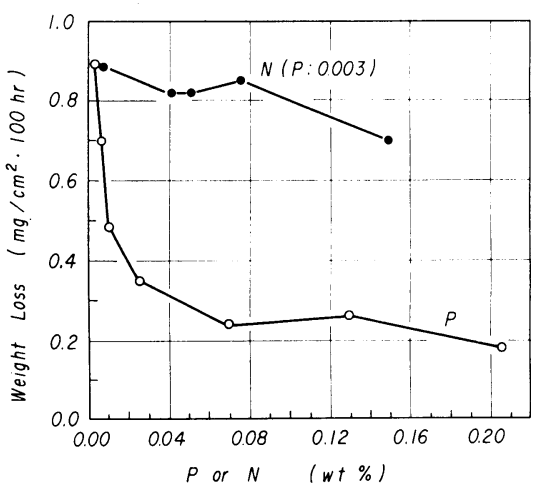

Fig.6 Effect of phosphorus or nitrogen on the corrosion rate of $18 \mathrm{Cr}-10 \mathrm{Ni}$ stainless steels in $\mathrm{MgCl}_{2}$ solution boiling at $154^{\circ} \mathrm{C}$

およびNを若干多く含んだ No. 52 鋼は No.4 鋼と No. 54 鋼の中間ぐらいである.したがって $\mathrm{P}$ と $\mathrm{N}$ の腐食挙動にお よぼす影響をさらに詳細に検討した結果を Fig.6に示す. 浸漬後 100 時間の腐食量を示しているが, Pはきわめて微 量でも沸騰 $\mathrm{MgCl}_{2}\left(154^{\circ} \mathrm{C}\right)$ 溶液中での耐食性に著しい影響 をおよぼすが，Nは比較的影響が少ないようである。

\section{4. 電位-時間曲線}

沸騰 $\mathrm{MgCl}_{2}\left(154^{\circ} \mathrm{C}\right)$ 溶液中で $\mathrm{P}$ が著しく耐食性に効果の あることが明らかとなったので, 主な供試材について応力 腐食割れ試験中の電位の経時変化を検討した.

6000 分以上割れを起こさない程度の応力を付加した場 合の電位変化を Fig.7 に示す. P含有量の多いNo.54 鋼 の限界応力である $5 \mathrm{~kg} / \mathrm{mm}^{2}$ で実験した結果，電位は応力 を付加後，急激に貴な方向に立上っている，一定した電位 
も他の鋼種に比較して若干高い傾向にある。また $\mathrm{N}$ 含有量 の多いNo.18 鋼では No. 54 鋼はどではないが, 電位は若 干貴になり，一定になる電位も若干高いようである。しかし $\mathrm{P}$ 济ど明らかな傾向は認められない，Pおよび $\mathrm{N}$ 含有量の 若干多い No. 52 鋼もほぼ No.18 鋼と同じ挙動を示す.P およびNの含有量の高い鋼種に反して，耐応力腐食に割れ 性のすぐれた No.4 鋼の場合は電位の貴になる速度が緩や かで,かつ一定となる電位も若干卓であることが判明した。 つぎにさらに高い応力を付加して破断した場合の電位変化 をFig.8 亿示す．P含有量の高い No.54 鋼は限界応力以 下の破断しない場合には，Fig.7 の如き変化をするが，30 $\mathrm{kg} / \mathrm{mm}^{2}$ の応力では電位は貴な方向に立上って $-370 \mathrm{mV}$ 程度でそれ以上立上れず破断至っている。 また $20 \mathrm{~kg} /$ $\mathrm{mm}^{2}$ の応力では一 $340 \mathrm{mV}$ 程度まで電位は貴になるが，お そらく Hines らが述べているょうに，表面での皮膜の破 れあるいは忘力腐食割れの発生によって，これ以上電位 は貴になれず 120 分前後で破断に至っている．Nの含有量 の多いNo.18 鋼についても同様で, $30 \mathrm{~kg} / \mathrm{mm}^{2}$ の応力で $-340 \mathrm{mV}$ 程度で一定となり約 200 分程度で破断している。

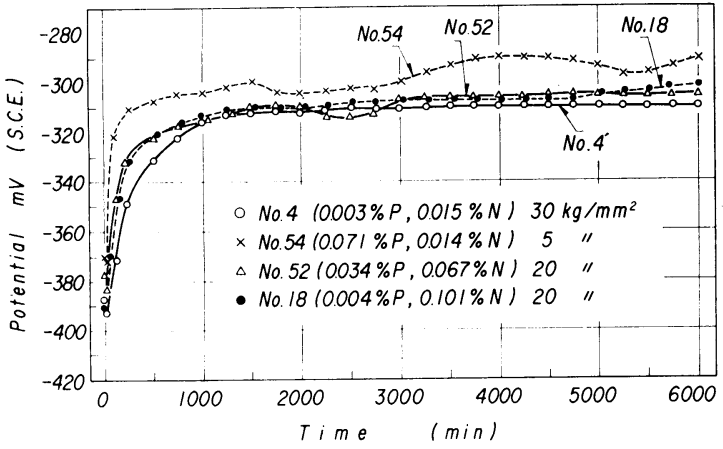

Fig.7 Potential vs time curves on several specimens applied stress of $5 \sim 30 \mathrm{~kg} / \mathrm{mm}^{2}$ in $\mathrm{MgCl}_{2}$ solution boiling at $154^{\circ} \mathrm{C}$

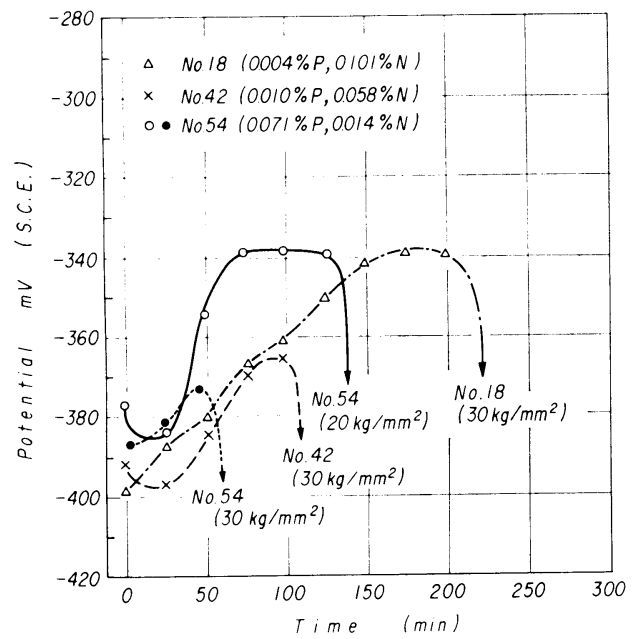

Fig. 8 Potential vs time curves on several specimens applied stress of $20 \sim 30 \mathrm{~kg} / \mathrm{mm}^{2}$ in $\mathrm{MgCl}_{2}$ solution boiling at $154^{\circ} \mathrm{C}$
またP拈よびNを若干多く含有した No.42 鋼についても 同様の挙動を示している.

\section{IV. 考察}

沸騰 $\mathrm{MgCl}_{2}$ 溶液での応力腐食割れに打よぼす微量元素 の影響についてはいくつかの報告があるが，それらは通常 含まれている量 $(0.020 \sim 0.040 \mathrm{wt} \% \mathrm{P})$ に比較して著しく 多量のPを添加して応力腐食割れ試験を行ない，その寿命 が短くなることから Pは応力腐食割れに対して悪影響があ ると結論しているにすぎないまたNについては研究者に より効果が異なって報告されている．これらのことは基本 成分あるいは応力腐食割れに影響を扣よぼす他の重要な元 素を考慮していなかったり，また調べた $\mathrm{N}$ 量の範囲が異な っているために統一的な結論が得られていないものと思わ れる。

本研究ではそれらの点に着目して $\mathrm{P}$ おび $\mathrm{N}$ 悪影響が ぞの程度かを明らかにし，さらにその影響を取り除くため には，どの程度まで低減させる必要があるかを詳細に検討 し, $18 \mathrm{Cr}-10 \mathrm{Ni}$ 鋼を基本とする成分でも応力腐食割れを起 こさないP括よびNの関係を求めたものである (Fig.2).し たがって，Pのある範囲( $(0.003 \mathrm{wt} \%$ 以下)ではNは悪影響 を扣よぼさない（約 $0.08 \mathrm{wt} \%$ 以下）ともいえるし，Pが少 しでも多く鋼中に含まれるとNは著しく悪影響を扰よぼす ようになる。この範囲は $\mathrm{Ni}$ 量の増加とともに拡大されて いくのが Fig. 3 叔よび 4 より明らかである.

このよ5に応力腐食割れに対して著しく悪影響をおよぼ す $\mathrm{P}$ および $\mathrm{N}$ の作用について薄膜の直接観察, 腐食量およ び電位変化の測定を行なった．薄膜の直接観察の結果, 転

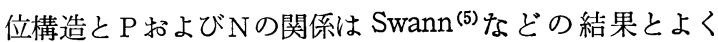
対応している．また腐食量の測定の結果，応力腐食割れ感 受性を高める P の含有量の多い材料は，耐応力腐食割れ性 のすぐれた材料に比較して腐食量が少ない傾向がある。こ の点も沸騰 $\mathrm{MgCl}_{2}$ 溶液中では活性溶解する領域とすると， 全面腐食性との関係より一応推測される結果である。つぎ に電位の経時変化を測定した結果によると $\mathrm{P}$ 含有量の多い 材料に比較して, 応力腐食割れ感受性の低い材料ほど電位 は時間とともに徐々に貴に移行する，また一定する電位も 若干卑になる傾向が認められる．このことは表面皮膜と関 連していることを示するのであろ5.さらにDouglassら (13) の述べているように，P拉よびNの富んだ微細な偏析部が 括そらく存在し，この部分がカソード部となるためである 3. しかしこのカソード部の周辺では水素発生によって皮 膜が生成しにくく，常に新しい面を曝らすため，局部的な 腐食が進行すると考えられる，局部的な腐食が進行した部 分は応力集中を起こし，著しい腐食速度で発展してゆくと 考えられる.

(13) D.L.Douglass, G.Thomas and W.R.Roser : Corrosion, 20 (1964), No.1, 15 t. 


\section{V. 結言}

$18 \mathrm{Cr}$ - (10〜15) Ni 鍓を基本とするオ一ステナイト系ステ

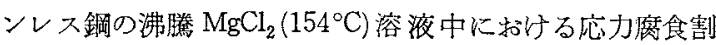
れに和よぼす微量のP扎よびNの影響を調べた，実験は U-bend 法打よび定荷重法に上る応力府食割れ試験, 転位 構造との関連, 腐食量の測定括よび電位变化の测定を行な った結果,つぎの結論が得られた。

(1) U-bend 法に上る応力腐食割狆試験の結果, $18 \mathrm{Cr}$ $10 \mathrm{Ni}$ 銅を基本とする場合， $0.003 \mathrm{wt} \% \mathrm{P}$ 以下では約 0.08 wt\% $\mathrm{N}$ を含む豆で応力腐食割れを起こさ始が，0.003〜 $0.010 \mathrm{wt} \% \mathrm{P}$ を含有するとNが著しく悪影響をおよぼす ようになる。これ以上のPを含有すると Nの含有量にかか わらず割れを起こすようになる。 Ni 量を增して $18 \mathrm{Cr}-13.5$ $\mathrm{Ni}$ 鋼を基本とする場合，Nの悪影響が弱まり割れを起こさ 双領域が顕著になる。さらに $18 \mathrm{Cr}-15 \mathrm{Ni}$ 銅を基本とした 場合，Nの悪影響がきわめて小さくなる。この事実によっ
て耐応力腐食割れ性のすぐれたオーステナイト系ステンレ ス鋼を製造することが可能となる。

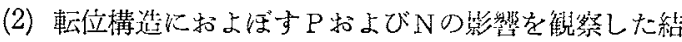
果ではSwannの観察とほぽ一致して括り，平行な転位配 列を示した。一力応力腐食割机感受性のすぐれたものは $5 \%$ 引張加工で若干転位がもつれたような傾问が認めら れる。

(3) 沸騰 $\mathrm{MgCl}_{2}\left(154^{\circ} \mathrm{C}\right)$ 溶液中て応力を付加せずに腐战 量を測定した結果，P注しく耐食性を向上させるが，N はそれ孚ど顕著ではないまた応力腐食割れ感受性のすぐ れたものは若干臂食量は多いようである。

（4）応力腐食割れ試験のさいの電位の経時変化を調べた 結果，P西るいはNを多く含有したものは電位が急激に貴 になるが，応力腐食割礼感受性のすぐれたものは貴になる 速度が緩やかである。

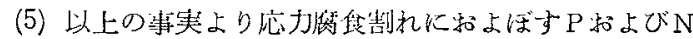
の效果について考察した。 